\title{
Animals in The Mayor of Casterbridge
}

\author{
Qin Liu $^{1}$ \\ ${ }^{1}$ School of Foreign Language, Yancheng Normal University, Yancheng, China \\ Correspondence: Qin Liu, School of Foreign Language, Yancheng Normal University, Yancheng, China. E-mail: \\ hobbyc@163.com
}

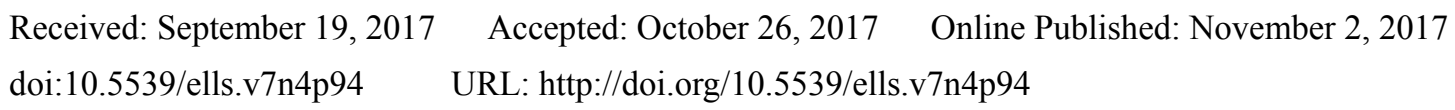

\begin{abstract}
Thomas Hardy, one of the outstanding writers in the 19th century. The Mayor of Casterbridge, is Hardy's masterpiece. As an enthusiastic lover of nature, natural description is of great importance in Hardy's novels. In The Mayor of Casterbridge, Hardy associates the presence of nature especially the animals to the characters' conditions. In the novel, Hardy endowed the "inhuman" animals with human characteristics. This paper will interprete the novel from the perspective of animals. It will explore the associations between the recurring bird image and Henchard's tragic fate, the close similarities between the bull and Henchard's characteristics, and the sheep as the symbolic representation of vulnerable women in the novel.
\end{abstract}

Keywords: The Mayor of Casterbridge, Thomas Hardy, animals

\section{Introduction}

Thomas Hardy was influenced by the idea of "Immanent Will", as a writer, he showed great intrest in exploring the causes of human tragedy, he believed that human beings like other animals in the universe are the preys of the indifferent and cold world. In The Mayor of Casterbridge, the recurring images of bird, bull and sheep are employed by Hardy to demonstrate that the tragedies happened to the human beings are just the minatures of the whole universe, the fate of the mankind as well as the animals are all controlled by mysterious universal force. No one can change the predestined fate no matter how hard he tried. The bird can not escape from the cage, the bull can not avoid being slaughtered for sacrifices, and the sheep is vulnerable and weak and can only be sold at the fair without the protections from the shepherd. In The Mayor of Casterbridge, Hardy exhibits the inevitable tragedy through the rich symbolic representations of bird, bull and sheep.

\section{Symbolic Representation of Bird}

Animal frequently appeared in Hardy's novels, and of all animals, it seems that Hardy has special interest in birds, because the image of birds appears a lot in his novels, especially in The Mayor of Casterbridge. John Alcorn believed that animals, and the human attitude towards materials are the source of Hardy's literature creations in his book The Nature Novel from Hardy to Lawrence (Alcorn, 1977). According to Hardy, every living being in the world is like the caged birds that can not get away from their destined fate no matter how hard they tried. Human being and the birds are both the preys of "Immanent Will" (Rabbets, 1989). Hardy's frequent use of the symbols of birds implies that the tragedy of Henchard is also the tragedy of mankind, because "The people in this tragedy laugh, sing, smoke, toss off wines, etc; and yet are playing their parts in the tragedy just the same: All are caged birds; the only difference lies in the size of the cage. This too is part of the tragedy" (Pinion, 1984). Human beings are just like the birds, can not escape from the cage, people can only choose the size of the cage. The difference between the poor and the rich is also the size and appearance of the cage, the poor people live in the shabby small iron cage, and the rich live in the extravagant large golden cage, both the poor and the rich can not live freely in the world.

At the beginning of the novel, a weak bird appeared firstly at the beginning of the novel which implies the tragedy of the protagonist. "For a long time there was none, beyond the voice of a weak bird singing a trite old evening song that might doubtless have been heard on the hill at the same hour, and with the self-same trill, quavers, and breves, at any sunset of that season for centuries untold" (Hardy, 2010, p. 5). It is not difficult for us to realize that the "weak bird" implicates Henchard's loneliness and desperation since he got married with Susan. There was no conversation between Henchard and his wife, the total absence of conversation allowed the sound of a weak bird to be heard. Henchard's fate and living conditions is linked to the birds, he had grow to be "a 
weak bird" who had no strong will and enthusiasm in life after years of marriage, he would soon die if he did not make any changes to his life. The appearance of "a weak bird" implies the terrible spiritual status of the protagonist. It is time for Henchard to make changes to his life to gain strength and power like "the weak bird".

A swallow appeared when Henchard decided to sell his wife and daughter. "At the moment a swallow, one among the last of the season, which had by chance found its way through an opening into the upper part of the tent, flew to and from quick curves above their heads, causing all eyes to follow it absently" (Hardy, 2010, p. 10) At this moment, Henchard fall into the abyss of confusion towards his life. Henchard wants to be a free man, and he wants to get rid of his marriage just like the swallow flies away from the confinement of the tent, because he believed that his marriage impededhis development. He described his marriage with Susan as "an early imprudent marriage" which weakened his energies and hindered the development of his career. He ascribed his failure in life to his imprudent early marriage. Henchard aspired to be a free man who can pursue for his splendid future rather than a nameless average person impeded by the burden of his marriage. He longed to fly high in the sky just as the swallow did. However, he can not escape from his own fate although his strength and energy can drive him to fly higher like a bird in the sky. The swallow hovered over his head implied that the fate of Henchard would be a full circle, he would return to his original beginning no matter how hard he tried. All his efforts and hard work turned out to be useless in front of the "Immanent Will".

In the end of the novel, Henchard, who now became a poor hay-trusser again just like 25 years ago, bought a caged goldfinch as a wedding gift to Elizabeth Jane. "Mrs Donald Farfrae had discovered in a screened corner a new bird-cage, shrouded in newspaper, and at the bottom of the cage a little ball of feather-the dead body of a gold finch. Nobody could tell her how the bird and cage had come there, though that the poor little songster had been starved to death was evident" (Hardy, 2010, p. 373). The caged goldfinch is also the token of Henchard's repentance. However, his final compensation can not win Elizabeth Jane back, and he is not willing to make any futile explanations to annoy his daughter, so he left alone sadly, and eventually died in the wilderness of Egdon as poorly as the caged goldfinch. The hopeless death of the gold finch was caused by the coldness and indifference of the people, and the painful life of Henchard also ends up in agony because of his unchangeable destined fate. Both of them can not change their fate and gain freedom. Henchard's fate is closely linked to the bird's, both lived and died in a prison. Henchard is also the "caged bird" dying to death for starvation. The goldfinch died because of no foods, and Henchard died due to the shortage of human caring.

Hardy employed the image of the bird in The Mayor of Casterbridge twenty two times. The frequent appearances of the image of the bird make it clear that the tragedy of Henchard is just a miniature of the tragedy for all human life. To some extent, the bird is the incarnation of the human being.

\section{Symbolic Representation of Bull}

Thomas Hardy is good at employing the image of animals to express his intentions in the novel. Apart from the image of the bird, bull is another symbolic image Hardy employed to reflect the protagonist's character and fate. In the Bible, the bull stands for "the strength of an unicorn" (Number, 23:22) which can not get rid of its tragic ending because the bulls are often killed for offering sacrifices.

In The Mayor of Casterbridge, the protagonist Henchard is compared to the bull in many ways consciously or unconsciously. Henchard himself also expressed much fondness for the bull, he even decorate his chimney-piece with "a draped ox-skull" (Hardy, 2010, p. 373). Henchard's special likeness for the bull implied that he longed to gain power and strength that can be employed to make others afraid. Henchard's characters resembled the characteristics of the bull. His impulsiveness and extremity are shown all through his life. As people who are familiar with him summarized his characters as "Loving a man or hating him, his diplomacy was as wrongheaded as a buffalo's" (Hardy, 2010, p. 134). He refused to solve all of his troubles by encouraging Farfrae to be his son-in-law, "But such a scheme for buying over a rival had nothing to recommend to the Mayor's headstrong faculties. With all domestic fitness of that kind he was hopelessly at varience" (Hardy, 2010, p. 134). $\mathrm{He}$ insisted on the fair competition to win over his rivals and he was against any illegal finesse in business. He was as stubborn as a bull. Even when he was forced to declare bankrupt, he was no willing to trade his honest with money to pay off his debts. He handed out all his money and possessions to the debtors and creditors without any concealment. He was the most honest and fair debtor in the town which aroused sympathic and pitful reaction towards his downfall. He was like the defeated bull with respects.

However, no matter how hard Henchard tried, he can not get away from his tragic ending, he was just like the bull in the Bible which can not escape from being slaughtered. In The Mayor of Casterbridge, bull was a very common animal in the town, bull stake had appeared five times in the novel. Hardy gave a vivid description of the bull stake in the novel. "The neighbouring Market House and Town Hall abutted against its next neighbour 
the Church except in the lower storey, where an arched thoroughfare gave admittance to a large square called Bull Stake. A stone post rose in the mist, to which the oxen had formerly been tied for baiting with dogs to make them tender before they were killed in the adjoining shambles" (Hardy, 2010, p. 225). The bull was so strong that they had to be tied to make them tender before they were killed. Henchard was just like the bull, he was so strongminded that he had to be made tender by all kinds of hardships. And the only fate for him was to be killed at last. Henchard can not escape from his predestined tragic ending just like the bull.

Hardy gave a vivid description of Henchard's conquering a wild bull to save lucetta and Elizabeth Jane, in which he showed his physical power during the course of his fight with the bull. In one case, Elizabeth and lucetta came across a bull who was "a large specimen of the breed, in colour rich dun, though disfigured at present by splotches of mud about his seamy sides. His horns were thick and tipped with brass; his two nostrils like the Thames Tunnel as seen in the perspective toys of yore" (Hardy, 2010, p. 241). Both Elizabeth and Lucetta was terrified by this large bull and ran wildly for safety, luckily, Henchard appeared in the time of danger and "seized it, and wrenched the animal's head as if he would snap it off. The wrench was in reality so violent that the thick neck seemed to have lost its stiffness and to become half-paralyzed, whilst the nose dropped blood" (Hardy, 2010, p. 242). In this scene, the violent and fierce bull can be seen as a reflection of Henchard himself. Very similar to the bull, Henchard was also a life threat to Lucetta and Elizabeth. And no matter how powerful Henchard was, he was defeated at last by his rival Farfrae step by step and forced to become a hay-trusser again in the end of the novel. It could be implied that Henchard's downfall resulted more from his impulsive and bullheaded temper. There are close resemblences between the bull and Henchard.

\section{Symbolic Representation of Sheep}

In The Mayor of Casterbridge, sheep is employed to represent the women who were at a disadvantage in the patriarchal society. In the western culture, sheep is often regarded as an animal of docile temperament. And in The Mayor of Casterbridge, the image of the sheep appeared more than once to demonstrate the characters' different physical and mental status.

At the beginning of the novel, Henchard and his wife first entered the Fair-field, the standing places and pens attracted the eyes of the couple, hundreds of sheep were sold in the market. Henchard was inspired by the sales of the sheep, and he got rid of his wife just like the businessman did to the sheep. After being drunk, he auctioned his wife just like the sheep in the market. "I'll sell her for five guineas to any man that will pay me the money, and treat her well; and he shall have her for ever" (Hardy, 2010, p. 11). Susan was sold to a sailor just like the sheep for five guineas. In this scene, it can be inferred that the social status of the women was not better than the conditions of the sheep in the market in the patriarchal society. Women were taught to obey his husband just like the sheep must obey the shepherd. The women were regarded as the personal belongings of the men after marriage. The women had to do almost everything the husband asked them to do, and they had to take care of the family and children without any complaints. Since they were born, the women were taught to be as docile as the sheep. To some extents, the image of the sheep is a good reflection of women in the patriarchal society.

When Susan left with the sailor, people in the market have faith in her good life ever since because "For seafaring natures be very good for shorn lambs, and the man do seem to have plenty of money, which is shat she's not been used to lately, by all showings" (Hardy, 2010, p. 14). Here, the image of the lamb was employed to symbolize the weak status of the women who had to rely on the stronger ones to survive in the world just like the "shorn lambs". In the patriarchal society, women were the weak group in the society, they seldom have the opportunities to go out to work in the man-dominated society. In fact, the controlled group of the men did not allow the women to threaten their superior role in the society. What is more, the education the women receive since their childhood also did not make them qualified to get a job to support themselves independently. Therefore, the only choice for the women to get happiness in the patriarchal society was to depend on the men's protection like the sheep. Women would become vulneral like the "shorn lambs" without the protections and support from the men. In The Mayor of Casterbridge, the image of the sheep is a useful symbolic representation for the vulnerable woman.

\section{Conclusion}

In The Mayor of Casterbridge, Hardy showed his great talents in describing the natural environment. Different from the traditional description of the natural scenes, in which nature only appear as an ornament, Hardy dexterously associated the presence of nature to the characters in the novel. Animals are frequent symbolic images in The Mayor of Casterbridge. To conclude, Hardy's effective and artistic usage of symbolic images of animals vividly demonstrate characters' variable conditions. The recurring images of bird, bull and sheep not only set up an impressive atmosphere but also enrich the novel with variable connotations to some extents. 


\section{Acknowledgements}

This work is supported by Top-notch Academic Programs Project of Jiangsu Higher Education Institutions.

\section{References}

Abravanel, G. (2005). Hardy's transatlantic Wessex: contructing the local in The Mayor of Casterbridge. Novel: A Forum on Fiction, 39(1), 97-117. https://doi.org/10.1215/ddnov.039010097

Alcorn, J. (1977). The Nature Novel from Hardy to Lawrence. Thought, 52(2), 219-221. https://doi.org/10.5840/thought197752234

Gerdabi, H. (2017). Characters' Names in the Shade of Literary Tendencies: An Onomastic Approach to Characters' Names in The Mayor of Casterbridge, A Portrait of an Artist as a Young Man, and The City of Glass. Interdisciplinary Literary Studies, 19. https://doi.org/10.5325/intelitestud.19.1.0125

Hardy, T. (2010). The Mayor of Casterbridge. New York: Bantam Books Press.

Keen, S., \& Hardy, T. (2016). Time and Narrative: A Narratological Approach to his Novels by Ken Ireland (review). Victorian Studies, 58.

Koehler, K. (2016). "Essentially separated in spite of all uniting factors": Thomas Hardy and the Community of Letter Writers. Victorian Review, 41. https://doi.org/10.1353/vcr.2016.0013

Moynahan, J. (1956). The Mayor of Casterbridge and the Old Testament's First Book of Samuel: A Study of Some Literary Relationships. Pmla, 71(1), 118-130. https://doi.org/10.2307/460196

Paterson, J. (1959). "The Mayor of Casterbridge” as Tragedy. Victorian Studies, 3(2), 151-172.

Pinion, F. B. (1984). A Wordsworth companion: survey and assessment. London: Macmillan. https://doi.org/10.1007/978-1-349-05718-4

Rabbetts, J. (1989). From Hardy to Faulkner: Wessex to Yoknapatawpha. American Literature, 62(2), 343. https://doi.org/10.1007/978-1-349-19765-1

Showalter, E. (1979). The Unmanning of the Mayor of Casterbridge.

\section{Copyrights}

Copyright for this article is retained by the author, with first publication rights granted to the journal.

This is an open-access article distributed under the terms and conditions of the Creative Commons Attribution license (http://creativecommons.org/licenses/by/4.0/). 